Indexes arranged according to subjects and to authors are provided. The importance of the work of the Institute of Plant Industry, the extent of its activities, and the diversity of its serial and non-serial publica. tions, make its bibliographical publications indispensable to applied botanists.

\section{Ocean Transportation of Petroleum in Bulk}

OwING to world trade depression and to production problems within the industry, there is now actually available excess oil tanker tonnage over demand. Of the world's steam tanker tonnage 44 per cent is, however, more than fifteen years old, consequently new tankers will shortly have to be constructed to replace these and to meet anticipated increase in demand when trade recovers. Mr. R. F. Hand read a paper on April 5 before the North East Coast Institution of Engineers and Shipbuilders, in which he indicated some of the problems attendant on ocean transportation of petroleum in bulk. Great care must be exercised in allocating vessels for specific work, account being taken of condition, size, position and capability of the tanker to carry the cargo in question. Freights cannot be imposed on a basis of cost plus a reasonable margin of profit, but must be fixed at a rate which the traffic can bear. Ultimate profit must be envisaged over a number of years, and provision made for periods when goods may actually have to be carried at a loss. A classification is suggested for petroleum products from the point of view of marine transport and types of vessel most suitable for carrying the various grades indicated. Operating costs are difficult to assess at the present time owing to the complex foreign exchange situation; but such data as are available prove that though the motor tanker is more economical for long hauls it is not always so in the case of short hauls.

\section{The Science Museum}

According to the Report of the Science Museum for the year 1934 (London: H.M. Stationery Office, $1935,1 s$. net) well over a million visitors have made use of the Museum, including more than a thousand organised groups and parties of about thirty, and the attendances at lectures were well over 30,000. The policy of holding special exhibitions to illustrate the advance of science into industry has been most successful, and the attendance at those on refrigeration from April until September 1934 and on rubber from November 1934 until April 1935 was very gratifying. 'The children's gallery has been visited by 13,000 children in school parties, and the introductory collection installed there has proved very attractive. Short accounts are given in the Report of the progress in each of the five divisions: industrial machinery and manufactures, mechanical and civil engineering, air and water transport, mathematics, astronomy and chemistry, physics and geophysics, and it is quite evident that the delay in reconstructing the central block is a serious obstacle in the way of a more instructive display of the material now crowded into inadequate cases. The Science Library now possesses a quarter of a million books, and nearly 50,000 readers have made use of them. The free space for new books is nearly exhausted and temporary housing will have to be provided until the central block becomes available.

\section{Fuel Research Institute of South Africa}

DR. J. G. VoGEL, director of the Fuel Research Institute of South Africa, has recently described the activities of the Institute (S. African J. Sci., 31, 194-209, Nov. 1934). Initially, the Union Government wished to encourage the export trade in coal, and prevent the damaging effect on the export of coal of unreliable grade. Now all coal loaded for export or bunkers must be graded by the Institute before shipment. The programme is determined by the fact that the coal industry is neither very old nor extensive, and the information available is limited. A first step is therefore a chemical survey. Already the Institute has made a notable contribution to the difficult problem of coal sampling by devising a novel sampling device. It consists essentially of a rotary drill working inside a sheath, up which a rapid current of air passes. The air and the coal abraded by the drill are drawn into a container after the manner of a vacuum cleaner, where the solids are retained. This apparatus not only enables samples to be collected from seams, but also from waggons-a problem which has not hitherto received a satisfactory solution. The Institute is equipped for research in coal chemistry and coal processing, and also for the study of liquid and gaseous fuels.

\section{Census Statistics}

THE normal series of publications dealing with the figures of the 1931 census is completed by the issue of General Tables, a volume of some two hundred and fifty pages (London : H.M.S.O. 11s.). It contains tables giving the populations by sex of the constituent regions of England and Wales-counties, boroughs, urban and rural districts-showing the changes that have occurred in recent intercensal periods. It also gives an analysis of the age and marital condition of the population at successive censuses during the last ninety years. Particulars are given of the birth-places and nationalities of the population in regions, boroughs and other urban areas, and comparative figures for England and Wales at successive censuses. There are also figures of population speaking the Welsh language. Much of the information given in the volume has hitherto been obtainable only by laborious extraction from separate county records.

\section{The Imperial Institute}

WE have received the annual report of the Imperial Institute, recently presented by the director, Sir Harry A. F. Lindsay, to the Board of Governors (London: Imperial Institute, 2s.). This gives a general account of the activities of the Institute and details of many special investigations which have been made with Empire products. These comprise work on silk, cordage fibres, tung oil, shellac, hides and leather, oil seeds, tanning materials, drugs and insecticides, 
and the analyses and investigations of various minerals. The report directs attention to the wide range of valuable minerals produced in the Union of South Africa. The use made by the public of the exhibition galleries, and the provisions made for educational purposes are dealt with in the report, which indicates clearly the very useful purposes served by the Imperial Institute.

\section{The Italian Seismological Society}

THIs well-known Society has now existed for forty years, and the first number of the new volume of the Bollettino $(33,10-21$; 1935) contains a brief survey of its history by the present secretary, Prof. G. Agamennone. The study of earthquakes as a whole in Italy may be said to have begun in 1870 with the works of Bertelli and De Rossi ; but the issue of the Bullettino del Vulcanismo Italiano, founded by the latter in 1874, was declining after twenty years. The Italian Society, in imitation of its Japanese predecessor, was founded in 1895 under the direction of Prof. P. Tacchini, the director of the Central Office of Meteorology and Geodynamics, and continued ten years later under that of his successor Prof. L. Palazzo, the present president being Prof. G. Cicconetti. The activity of the Society may be judged from the volumes of the Bollettino so far published, which contain nearly 500 papers occupying more than 9,000 pages.

\section{Cambridge Microtomes}

THIs year the Cambridge rocking microtome, one of the most familiar instruments in biological laboratories, attains its jubilee. The Cambridge Scientific Instrument Co., Ltd., has issued a new folder, illustrating this instrument and also a more heavily built and modified form of it for cutting flat sections of larger objects. The folder shows in addition a massively built sliding microtome, the design of which was completely overhauled two years ago, which cuts large sections, $60 \mathrm{~mm} . \times 60 \mathrm{~mm}$, in either paraffin or celloidin, and a freezing microtome of new design. Hints on the care and sharpening of microtome knives are added.

\section{International Society of Leather Trades' Chemists}

THE bi-annual conference of the International Society of Leather Trades' Chemists, in conjunction with that of the Internationalen Vereins der Leder Industrie Chemiker, will be held on September 1-6 at the Institut des Arts et Metiers, 50 Boulevard de l'Abattoir, Brussels, Belgium. The reception of members and visitors will take place on Sunday evening, September 1, at 8 p.m., at the Palace Hotel, Place Rogier, while the official banquet, at which the Burgomaster of Brussels will be present, together with other representatives of civic, commercial and scientific bodies, is fixed for Wednesday, September 4 . Some thirty papers are to be read and discussed. Further details can be obtained from M. A. Fievez, 7 rue d'Audiger, Soignies, Belgium, or from the Honorary General Secretary of the I.S.L.T.C., 17 Market Street, London, S.E.1.

\section{Announcements}

Prof. J. A. Nrxon and Dr. R. E. Lane have been appointed to fill vacancies in the membership of the Industrial Health Research Board.

THE following appointments have recently been made by the Secretary of State for the Colonies: Mr. A. W. Gledhill, to be veterinary officer, Uganda; Mr. R. M. Davies, district agricultural officer, Tanganyiki, to be senior agricultural officer; Mr. S. P. Teare, game ranger, Tanganyika, to be game warden.

THE Managers of the Royal Institution have awarded the Dewar research fellowship to $\mathrm{Mr}$. A. R. Ubbelohde, formerly Senior Scholar of Christ Church, Oxford, and at present holder of a senior research award of the Department of Scientific and Industrial Research. Mr. Ubbelohde will take up his new appointment in the autumn. His researches have been largely in physical chemistry, and it is expected that his experience will be valuable in connexion with the researches directed by Sir William Bragg at the Royal Institution on the structure of matter.

Applications are invited for the following appointments, on or before the dates mentioned:

Scientific Officers (Ref. A. 764), junior scientific officers (Ref. A. 765), and assistants, grades I-III (Ref. A. 766-8) at the Royal Aireraft Establishment, South Farnborough, Hants-The Chief Superintendent (Aug. 17).

An assistant signals officer and a signals officer in the Signals Branch, Air Ministry-The Secretary (S 1, Room 436), Air Ministry, Adastral House, Kingsway, W.C.2 (Aug. 19).

A senior lecturer in the Department of Pure and Applied Science, Loughborough College-The Registrar (Aug. 24).

An engineer officer in the Public Works Department, Buildings and Roads Branch, Punjab-The High Commissioner for India, General Department, India House, Aldwych, London, W.C.2 (Aug. 26).

An assistant lecturer in the Department of Zoology, University of Leeds-The Registrar (Aug. 31).

An assistant lecturer in the Department of Physiology, University College of South Wales and Monmouthshire-The Registrar (Aug. 31).

A lecturer in morbid anatomy in the Department of Pathology, University of Aberdeen--The Secretary (Sept. 15).

A professor of mathematics in the University of Aberdeen-The Secretary (Sept. 30).

Temporary architectural and engineering assistants in the Directorate of Works and Buildings, Air Ministry, and at various aerodromes in the United Kingdom-The Secretary (W.B.9, Room 161), Air Ministry, Adastral House, Kingsway, W.C.2.

Temporary assistant mechanical and electrical engineers-The Secretary, Air Ministry (W.B.9), Adastral House, Kingsway, London, W.C.2.

A lecturer in geography and mathematics at St. Hild's College, Durham (Diocesan Training College for Women)-The Principal. 